ACTA UNIVERSITATIS WRATISLAVIENSIS

No 3779

Studia nad Autorytaryzmem i Totalitaryzmem 39, nr 1

Wrocław 2017

DOI: $10.19195 / 2300-7249.39 .1 .7$

JOANNA SONDEL-CEDARMAS

Uniwersytet Jagielloński

\title{
Retroaktywna „defaszyzacja faszyzmu” w interpretacji Emilio Gentilego
}

W 1923 r. włoscy publicyści antyfaszystowcy Giovanni Amendola i Luigi Salvatorelli, analizując sytuację polityczną we Włoszech rok po Marszu na Rzym, wprowadzili do języka politycznego terminy ,totalitarny” i ,totalitaryzm”, starając się opisać nowy rodzaj władzy politycznej, oparty na ,partii-milicji” — tzn. partii nowego typu, która zdobyła pełnię władzy w państwie przy użyciu własnej organizacji bojowej oraz instytucji państwowych, eliminując stopniowo z życia politycznego wszystkie partie opozycyjne i narzucając własną wizję państwa i społeczeństwa jako jedyną słuszną ideologię ${ }^{1}$. Pomimo że od upadku reżimu Mussoliniego upłynęło ponad 70 lat, włoski faszyzm ciągle stanowi źródło interpretacji oraz sporów współczesnych historyków i politologów nie tylko we Włoszech, lecz także za granicą. Szczególnie dużo wątpliwości budzi kwestia totalitarnego charakteru państwa faszystowskiego duce.

$\mathrm{Z}$ początkiem nowego stulecia na coraz szerszą skalę w życiu publicznym rozwinęło się zjawisko, które wybitny badacz systemów totalitarnych, emerytowany profesor uniwersytetu La Sapienza w Rzymie Emilio Gentile określił mianem ,,banalizacji faszyzmu” oraz ,retrospektywnej defaszyzacji reżimu Mussoliniego". Zjawisko to ma swoje źródła w memorialistyce oraz publicystyce

1 Już w lipcu 1922 r. Luigi Salvatorelli na łamach „La Stampa” pisał, iż „faszyzm jest ruchem, który próbuje przejąć władzę w państwie wszystkimi możliwymi sposobami i ustanowić pełną dyktaturę”, a w kwietniu 1923 r. dodawał: „faszyzm zaczyna tworzyć dyktaturę jednej partii, likwidując wszystkie partie opozycyjne". Podobnie też Giovanni Amendola na początku listopada 1923 r. stwierdzał: „najważniejszą cechą charakterystyczną ruchu faszystowskiego będzie dla przyszłych badaczy jego charakter totalitarny (spirito totalitario), który nie pozwoli w przyszłości na tworzenie innych ruchów, jak te, które używają pozdrowienia rzymskiego". Zob. L. Salvatorelli, Nazionalfascismo, Torino 1977, s. 83; G. Amendola, Un anno dopo, ,Il Mondo”, 2 listopada 1923, [w:] idem, In difesa dell'Italia liberale. Scritti e discorsi politici, 1910-1925, red. A. Carioti, Firenze 2001, s. 109-112. 
neofaszystowskiej, a także w tendencji historiografii antyfaszystowskiej w okresie powojennym do bagatelizowania znaczenia reżimu Mussoliniego w historii politycznej i społecznej Włoch. W konsekwencji już w latach 50. we włoskich środowiskach konserwatywnych ugruntowała się wizja łagodnej dyktatury faszystowskiej, pozbawionej cech totalitarnych i zasadniczo odmiennej od reżimu Hitlera oraz Stalina. Taka interpretacja - zapoczątkowana przez dziennikarza i jednego z wybitniejszych przedstawicieli świata kultury faszystowskiej Indro Montanelliego, który w książce Buonuomo Mussolini w 1947 r. stwierdzał m.in., że państwo policyjne duce ograniczyło się do „wypędzenia kilkuset antyfaszystów" ${ }^{2}$ - została następnie ugruntowana przez Hannah Arendt w studium Korzenie totalitaryzmu w 1951 r. Zdaniem włoskiej historyk Giovanny Belardelli ta polityka doprowadziła do powstania w latach 50. we Włoszech tzw. pamięci pobłażliwej (memoria indulgente).

Podobnie też nowe badania nad faszyzmem, zainaugurowane we Włoszech w drugiej połowie lat 60., mimo że prowadzone przez tak wybitnych historyków, jak Renzo De Felice, Roberto Aquarone i Piero Melograni, pozostawały pod wyraźnym wpływem interpretacji Arendt i również negowały totalitarny charakter reżimu Mussoliniego. W szczególności studia De Felice zostały skrytykowane przez środowiska antyfaszystowskie za „próbę rehabilitacji faszyzmu”. Faktem jest, że chociaż autor Intervista sul fascismo od 1975 r. nie podważał już istnienia totalitaryzmu faszystowskiego, to jednak akcentując różnice pomiędzy nazistowskimi Niemcami i faszystowskimi Włochami oraz brak istnienia ideologii antysemickiej we włoskim faszyzmie, zdaniem części współczesnych badaczy, przyczynił się do rozwoju rewizjonizmu historycznego we Włoszech w latach $80 .{ }^{3}$ Dał temu wyraz włoski historyk Brunello Mantelli, który stwierdził, iż interpretacja faszyzmu De Felice stanowiła ,próbę złagodzenie zjawiska faszyzmu poprzez porównanie"4. Podobnie też szwajcarski badacz Aram Mattioli zauważył, że De Felice, przedstawiając dyktaturę Mussoliniego jako reżim nieszczególnie represyjny, nieporównywalny z III Rzeszą, pomijał zupełnie realia brutalnej wojny

2 Zob. I. Montanelli, Il buonomo Mussolini, Milano 1947, s. 98.

${ }^{3}$ Literatura na temat badań nad faszyzmem Rezo De Felice jest dość bogata. Wśród najważniejszych opracowań należy wymienić: L. Goglia, R. Moro, Renzo De Felice. Studi e testimonianze, Roma 2002; P. Simoncelli, Renzo De Felice. La formazione intellettuale, Firenze 2001; Alla ricerca dell'Italia contemporanea. Romeo, De Felice, Spadolini. Atti del convegno di studi svoltosi a Firenze il 21-22 novembre 1997, red. G. Giarizzo, Firenze 2002; G. Santomassimo, Il ruolo di Renzo De Felice, [w:] Fascismo e antifascismo. Rimozioni, revisioni, negazioni, red. E. Collotti, Roma-Bari 2003, s. 415-429; idem, Renzo De Felice e il fantasma di Mussolini, „Passato e presente”, styczeń-kwiecień 1998, s. 121-140; Interpretazioni su Renzo De Felice, red. P. Chessa, F. Villari, Milano 2002; J. Renner, Der neue Marsch auf Rom. Berlusconi und seine Vorläufer, Zürich 2002, s. 49-65; E. Gentile, Renzo De Felice. Lo storico e il personaggio, Roma-Bari 2003.

4 B. Mantelli, Fascismus, Geschichte Italiens, Selbstverständnis der Republik. Kritische Anmerkungen zür jüngsten Debatte über die Beziehung von Geschichte und Gegenwart, [w:] Faschismus und Faschismen im Vergleich. Wolfgang Schieder zum 60. Geburstag, red. C. Dipper, R. Hudemann, J. Petersen, Köln 1998, s. 99. 
kolonialnej w Etiopii oraz krwawej okupacji Libii, Etiopii i Bałkanów, a także fakt, że Włochy stały się $\mathrm{w}$ drugiej połowie lat 30 . najwierniejszym sprzymierzeńcem Hitlera i po utworzeniu Włoskiej Republiki Społecznej jesienią 1943 r. aktywnie pomagały w Holokauście, wysyłając do nazistowskich obozów zagłady ponad 8500 włoskich Żydów ${ }^{5}$.

Nie ulega wątpliwości, że na zmianę sposobu postrzegania faszyzmu we Włoszech wpłynęły nie tylko studia De Felice, lecz także zmieniony klimat polityczny w latach 80., cechujący się m.in. otwarciem Włoskiej Partii Socjalistycznej na współpracę z neofaszystowskim ugrupowaniem Movimento Sociale Italiano (MSI) ${ }^{6}$. Jak zauważył Mattioli, w okresie rządów premiera Bettino Craxiego (1983-1987) nastąpiła zmiana polityki historycznej we Włoszech i rozbicie jednolitego dotąd frontu antyfaszystowskiego $\mathrm{w}$ historiografii ${ }^{7}$. Z okazji setnej rocznicy urodzin duce w 1983 r. ukazały się liczne studia biograficzne faszystowskich gerarchów, takich jak Giuseppe Bottai, Italo Balbo, Galeazzo Ciano, Alessandro Pavolini czy Achile Starace. Na przełomie lat 80. i 90. powstały ponadto liczne filmy dokumentalne poświęcone Mussoliniemu i różnym dygnitarzom faszystowskim, ukazujące ich „ludzkie oblicze”, przede wszystkim jako troskliwych ojców rodziny i przykładnych obywateli ${ }^{8}$. Interpretacja faszyzmu jako stosunkowo łagodnej dyktatury rozpowszechniła się na jeszcze większą skalę w społeczeństwie włoskim po włączeniu Sojuszu Narodowego (Alleanza Nazionale), ugrupowania powstałego po rozłamie w MSI, do centroprawicowej koalicji rządowej premiera Silvio Berlusconiego w $1994 \mathrm{r}$.

5 A. Mattioli, „Viva Mussolini”. La guerra della memoria nell'Italia di Berlusconi, Bossi, Fini, Milano 2011, s. 46-47.

6 Jak zauważył Aram Mattioli, w latach 80. nastąpiło stopniowe zbliżenie pomiędzy socjalistami i MSI. W 1983 r. Bettino Craxi, tworząc swój rząd jako pierwszy premier w historii powojennych Włoch, konsultował jego skład z przedstawicielami neofaszystowskiej partii MSI oraz potępił izolację tego ugrupowania na włoskiej scenie politycznej. Podobnie też w maju 1985 r. prezydent Sandro Pertini spotkał się z liderem MSI Giorgio Almirante, żeby przedyskutować problemy polityczne współczesnych Włoch.

${ }^{7}$ Przykładem tej polityki było poświęcenie w 1986 r., pomimo protestów środowisk antyfaszystowskich, jednej z sekcji muzeum historycznego w miasteczku Frosinone marszałkowi Rodolfo Grazianiemu. Graziani, który będąc generalnym gubernatorem i wicekrólem Etiopii, wsławił się m.in. brutalną pacyfikacją plemion tubylczych, połączoną z użyciem broni chemicznej i tworzeniem obozów koncentracyjnych w Libii, Cyrenajce i Etiopii. W okresie Włoskiej Republiki Społecznej opowiadał się za współpracą z III Rzeszą i współpracował przy organizacji masowych wywozów Włochów na przymusowe roboty do Niemiec oraz brutalną pacyfikacją partyzantów włoskich.

${ }^{8}$ W 1982 r. drugi kanał publicznej telewizji Rai Due wyemitował film dokumentalny Nicola Caracciolo pt. Tutti gli uomini del duce, poświęcony Galeazzo Ciano, Italo Balbo i Dino Grandi, w 1985 r. Rai Uno wyemitował serial Io e il duce w reżyserii Alberto Nigrin, a w 1984 r. został nakręcony film pt. Claretta w reżyserii Pasquale Squitieri, poświęcony Clarettcie Petacci, z Claudią Cardinale w roli głównej. Film został przedstawiony na Festiwalu w Wenecji, wywołał skandal i protest jury. Zob. N. Tranfaglia, Fascismo e mass media: dall'intervista di De Felice agli sceneggiati televisivi, „Passato e presente” 1983, nr 3, s. 142 n. 
Na przełomie XX i XXI w. wizja faszyzmu jako „operetkowej dyktatury”, niekrwawej, zasadniczo różnej od reżimu Stalina i Hitlera, rozpowszechniła się nie tylko w środowiskach neofaszystowskich i postfaszystowskich, lecz także wśród zwolenników partii Silvio Berlusconiego. I tak w 2002 r., w 80. rocznicę Marszu na Rzym, wicepremier i lider AN Gianfranco Fini podczas wizyty w Izraelu stwierdził, że faszyzm nigdy nie stosował terroru, żeby zapewnić sobie masowe poparcie społeczeństwa, a wywodzący się z tej samej partii wicemarszałek senatu Domenico Fisichella zaliczył dyktaturę Mussoliniego do systemów autorytarnych. Podobnie ówczesny premier Silvio Berlusconi w 2003 r. stwierdził, że faszyzm był „dyktaturą umiarkowaną, która nikogo nie zabiła”.

Jak zauważył angielski historyk Paul Ginsborg, od początku nowego stulecia w dyskursie politycznym włoskiej centroprawicy faszyzm nie był postrzegany w negatywnym świetle. Znakomita większość Włochów była zdania, że „Mussolini został wprowadzony w błąd przez Hitlera i faszyzm obrał zły kierunek dopiero w 1938 r., kiedy wprowadził ustawy rasistowskie"9. O takim sposobie postrzegania faszyzmu w społeczeństwie włoskim na początku XXI w. świadczy również sondaż przeprowadzony w 2001 r. Jak wykazał politolog Piero Ignazi, w odpowiedzi na pytanie, czy reżim faszystowski można uznać za totalitarny, aż 22,4\% ankietowanych umieszczała go wśród systemów autorytarnych, 5\% uważała go za reakcję na zagrożenie komunistyczne, natomiast jedynie 38,1\% definiowała dyktaturę Mussoliniego jako dość brutalną ${ }^{10}$.

Niniejszy artykuł jest próbą analizy koncepcji „,wstecznej defaszyzacji dyktatury Mussoliniego" na tle interpretacji faszyzmu Emilio Gentilego. Należy zaznaczyć, że studia wspomnianego włoskiego historyka, ucznia Renzo De Felicego, nad źródłami i charakterem ideologii faszystowskiej zapoczątkowane w połowie lat 70., które przyniosły zasadniczy wkład w nową interpretację włoskiego faszyzmu jako systemu totalitarnego, są nadal w Polsce stosunkowo mało znane ${ }^{11}$. Tekst ma więc na celu wypełnienie istotnej luki w polskiej literaturze przedmiotu.

9 P. Ginsborg, Berlusconi, Ambizioni patrimoniali in una democrazia mediatica, Torino 2003, s. 137 n.

10 P. Ignazi, Extreme Right Parties in Western Europe, Oxford 2003, s. 51.

11 Emilio Gentile jest autorem licznych studiów na temat włoskiego faszyzmu. Wśród najważniejszych należy wspomnieć: idem, Il mito dello Stato nuovo. Dal radicalismo nazionale al fascismo, Roma-Bari 2002; idem, Le origini dell'Italia contemporanea. L'età giolittiana, Bologna 2009; idem, Fascismo e antifascismo. I partiti italiani fra le due guerre, Firenze 2000; idem, Renzo De Felice. Lo storico e il personaggio...; idem, La Grande Italia. Il mito della nazione nel XX secolo, Roma-Bari 2006; idem, Le religioni della politica. Fra democrazie e totalitarismi, Roma-Bari, 2007; idem, Il fascismo in tre capitoli, Roma-Bari 2009; idem, Il culto del littorio. La sacralizzazione della politica nell'Italia fascista, Roma-Bari 2003; idem, Fascismo di pietra, Roma-Bari 2007; idem, Fascismo. Storia e interpretazione, Roma-Bari 2005; Modernità totalitaria. Il fascismo italiano, red. E. Gentile, Roma-Bari 2008; idem, La via italiana al. totalitarismo. Il partito e Lo Stato nel regime fascista, Roma 2008; idem, Le origini dell'ideologia fascista 1918-1925, Bari 1975 (w wersji polskiej: idem, Poczatki ideologii faszystowskiej, Warszawa 2011); idem, The Struggle for Modernity. Nationalism, 


\section{Wsteczna defaszyzacja faszyzmu w interpretacji Emilio Gentilego}

W koncepcji Emilio Gentilego „wsteczna defaszyzacja faszyzmu” objawia się w tendencji — obecnej zarówno we współczesnej historiografii, jak i publicznej debacie - do pozbawiania faszyzmu jego atrybutów historycznych jako systemu totalitarnego oraz podważania oryginalnego charakteru jako partii politycznej i reżimu. W szczególności zjawisko to opiera się na potrójnej negacji: 1) negowaniu totalitarnego charakteru włoskiego faszyzmu, a co za tym idzie 2) przedstawianiu go jako personalnej dyktatury Mussoliniego stworzonej w oparciu o tradycyjne elity oraz 3) podważaniu istnienia „pozytywnej” ideologii faszyzmu.

Jak zauważył autor Il culto del littorio, włoska kultura antyfaszystowska w okresie dwudziestolecia międzywojennego opracowała pierwsze wartościowe analizy faszyzmu, które wykazywały jego charakter totalitarny. W latach 1923 1925 liberalni publicyści Giovanni Amendola oraz Luigi Salvatorelli opracowali teorię totalitaryzmu, zaliczając do cech tego zjawiska: 1) istnienie zorganizowanej partii o charakterze antydemokratycznym; 2) systematyczne użycie przemocy wobec przeciwników politycznych; 3) monopol sprawowania władzy; 4) narzucenie mitów faszystowskich jako religii politycznej; 5) wprowadzenie kultu duce; 6) stworzenie państwa-partii, które podporządkowało instytucje państwowe przywódcy partii faszystowskiej; 7) mobilizację mas pod kontrolą reżimu. Podobnie też twórca i lider Partito Popolare Italiano Luigi Sturzo, który w 1924 r. został zmuszony do opuszczenia Włoch, stwierdzał w 1926 r., iż „faszyzm postępował drogą w kierunku totalitaryzmu i absolutyzmu"12.

Należy zaznaczyć, że już w latach 20. włoscy antyfaszyści zwracali uwagę na podobieństwa istniejące pomiędzy reżimem Mussoliniego i reżimem bolszewickim, a po 1933 r. — również z systemem III Rzeszy. Podkreślali, iż były to systemy polityczne bazujące na istnieniu jednej partii i powstałe z ruchów rewolucyjnych o charakterze antydemokratycznym i antyliberalnym ${ }^{13}$. Wskazując na podobny charakter bolszewizmu, faszyzmu i narodowego socjalizmu, nie negowali charakteru totalitarnego faszyzmu, aczkolwiek dostrzegali jego mniej radykalny charakter i ograniczone posługiwanie się terrorem.

Do zakwestionowania totalitarnego charakteru faszyzmu po II wojnie światowej przyczynili się byli gerarchowie i intelektualiści faszystowscy, którzy od drugiej połowy lat 40. publikowali swoje wspomnienia, autobiografie i dzienniki, starając się przedstawić łagodne oblicze reżimu Mussoliniego, a także środowiska

Futurism and Fascism, Westport 2003; idem, E fu subito regime. Il fascismo e la Marcia su Roma, Roma-Bari 2012; idem, Storia del partito fascista 1919-1922. Movimento e milizia, Roma-Bari 1989.

12 Zob. L. Sturzo, L'Italie at le Fascisme, Paris 1927, s. 115.

13 Cyt. za: E. Gentile, La via italiana al. totalitarismo..., s. 54-67. 
neofaszystowskie, związane z powstałą w 1946 r. partią Movimento Sociale Italiano. Publicyści i politycy MSI, choć nie negowali, że faszyzm używał metod typowych dla totalitaryzmu, podkreślali, że nigdy nie stał się on w pełni systemem totalitarnym. W 1950 r. dziennik MSI „La Rivolta Ideale” pisał:

faszyzm jako idea nie ma nic wspólnego z totalitaryzmem, nabrał pewnych cech totalitarnych w latach 1924-25, kiedy partie opozycyjne opuściły Izbę Deputowanych i faszyzm stał się jedynym interlokutorem dla opinii publicznej we Włoszech i poza granicami. Totalitaryzm faszystowski stał się możliwy, ponieważ był Człowiek, który umiał wziąć cugle rządu i utrzymać je przez ponad dwadzieścia lat ${ }^{14}$.

Zgodnie z tą interpretacją Mussolini został zmuszony przez warunki historyczne do przejęcia władzy dyktatorskiej i w rezultacie „totalitaryzm faszystowski był konsekwencją wydarzeń historycznych, a nie ich źródłem".

W tym samym duchu wypowiadał się znany intelektualista faszystowski Camillo Pellizzi, który określał faszyzm jako „nieudaną rewolucję technokratyczną”, w której istnienie Kościoła i monarchii uniemożliwiło stworzenie masowego reżi$\mathrm{mu}$ o charakterze totalitarnym ${ }^{15}$. Analogicznie publicysta i historyk faszystowski Attilio Tamaro stwierdzał, że faszyzm był jedynie „zwykłą dyktaturą nacjonalistyczną" "16. Jak zauważył Emilio Gentile, ta interpretacja została w pewnym stopniu przejęta $\mathrm{w}$ okresie powojennym przez historiografię antyfaszystowską, która unikała prowadzenia pogłębionych studiów i badań historycznych nad tym okresem, starając się przedstawiać faszyzm ,jako zamknięty rozdział w historii Włoch". Zgodnie z tą koncepcją politycy i publicyści antyfaszystowscy wybierali raczej zabieg umniejszania znaczenia faszyzmu i jego wpływu na życie społeczne, polityczne i kulturalne Włoch. Znaczące dla tej tendencji jest stwierdzenie ówczesnego lidera Włoskiej Partii Komunistycznej Palmiro Togliattiego, który wyraził przekonanie, iż „faszyzm nie mógł skorumpować ducha społeczeństwa włoskiego, ponieważ dyktatura Mussoliniego była sprzeczna z mocno zakorzenioną tradycją obywatelską Włoch" ${ }^{\prime 17}$. Z kolei liberalny senator, wybitny filozof i historyk kultury, Benedetto Croce określił faszyzm jako wypadek w historii, a filozof polityki Norberto Bobbio stwierdził, że faszyzm posiadał jedynie ,ideologię negacji" i nie wypracował żadnej kultury politycznej ${ }^{18}$. Jak zauważył Emilio Gentile, jeszcze w latach 70. podważenie tezy o „nicości historycznej faszyzmu” było uważane za przejaw apologii faszyzmu.

${ }^{14}$ M. Bucciarelli, Democrazia Fascismo Totalitarismo, „La Rivolta Ideale”, styczeń 1951, nr 4. Cyt. za: E.Gentile, La via italiana al. totalitarismo..., s. 346.

15 C. Pellizzi, Una rivoluzione mancata, Milano 1949, s. 133.

16 A. Tamaro, Vent'anni di storia 1922-1943, t. 2, Roma 1953, s. 72-73.

17 Cyt. za: E. Gentile, La via italiana al. totalitarismo..., s. 347.

18 Zob. F. Focardi, Die Unsitte des Vergleichs. Die Rezeption von Faschismus und Nationalsozialismus in Italien und die Schwirigkeiten, sich der eigenen Vergangenheit zu stellen, [w:] Parallele Geschichte? Italien und Deutschland 1945-2000, red. G.E. Rusconi, H. Woller, Berlin 2006, s. 114 n. 


\section{Faszyzm jako włoska droga do totalitaryzmu — polemika Emilio Gentilego z interpretacją faszyzmu Hannah Arendt i Renzo De Felicego}

Chociaż nie można zaprzeczyć, że w latach 60. nastąpiła zmiana interpretacji faszyzmu we Włoszech, która przyniosła pierwsze nowatorskie i wolne od uprzedzeń ideologicznych i politycznych instrumentalizacji studia, niemniej jednak nie ulega wątpliwości, że włoskie wizje faszyzmu z tego okresu pozostawały pod wyraźnym wpływem interpretacji Hannah Arendt. Jak wiadomo, w koncepcji autorki Korzeni totalitaryzmu faszyzm aż do 1938 r. był jedynie dyktaturą nacjonalistyczną, która narodziła się z kryzysu systemu demokratycznego. Niewątpliwie wizja ta wywarła duży wpływ na włoską historiografię, znajdując m.in. odzwierciedlenie w istotnych interpretacjach faszyzmu opracowanych przez Renzo De Felicego i Alberto Aquarone'a ${ }^{19}$, które do dziś stanowią punkt odniesienia dla znakomitej większości badaczy włoskiego faszyzmu. W swoich studiach z lat 60. i pierwszej połowy lat 70. Aquarone i De Felice negowali totalitarny charakter reżimu Mussoliniego, przedstawiając go jako dyktaturę personalistyczną stworzoną na bazie kompromisu z tradycyjnymi instytucjami państwa monarchistycznego, pozostawiając nienaruszoną strukturę dawnego ustroju liberalnego. Jak stwierdził De Felice w 1968 r., faszyzm był jedynie „starym reżimem tradycjonalistycznym, w czarnej koszuli, który przeszedł szereg transformacji w kierunku autorytarnym" ${ }^{20}$. Podobnie też Aquarone w 1965 r. pisał, że faszym był jedynie „monokracją personalną"21.

Należy podkreślić, że Renzo De Felice zmienił zdanie na temat charakteru włoskiego faszyzmu w połowie lat 70. Począwszy od słynnego wywiadu opracowanego w 1975 r. wraz z amerykańskim historykiem Michaelem A. Ledeenem pt. Intervista sul fascismo, w którym wprowadzając rozróżnienie pomiędzy faszyzmem ,reżimem” (stanowiącym kompromis z siłami konserwatywnymi i reakcyjnymi) oraz faszyzmem „ruchem” (wywodzącym się z tradycji rewolucyjnej i interwencjonistycznej lewicy), De Felice zaczął skłaniać się do tezy o totalitarnym charakterze faszyzmu. W koncepcji cytowanego historyka faszyzm był jednak „totalitaryzmem lewicowym”, mającym swoje źródła w tradycji jakobińskiej oraz kulturze politycznej rewolucyjnej lewicy i w konsekwencji zasadniczo odmiennym

19 A. Aquarone, L'organizzazione dello Stato totalitario, Torino 1965.

20 Taką interpretacje można odnaleźć we wczesnych studiach De Felice poświęconych faszyzmowi, a w szczególności w Storia degli ebrei italiani sotto il fascismo z 1961 r. oraz w pierwszych trzech tomach biografii Mussoliniego, opublikowanych w latach 1965-1968 (zob. R. De Felice, Mussolini il rivoluzionario 1883-1920, Torino 1965; idem, Mussolini il fascista. La conquista del potere 1921-1925, Torino 1966; idem, Mussolini il fascista. L'organizzazione dello Stato fascista 1925-1929, Torino 1968).

21 Zob. A. Aquarone, op. cit., s. 164. 
od nazizmu ${ }^{22}$. Niemniej jednak De Felice nie zgadzał się z zakwalifikowaniem dyktatury Mussoliniego do tzw. pełnego totalitaryzmu, który identyfikował z nazizmem i stalinizmem. W kolejnych studiach opublikowanych w latach 1979-1981 stwierdzał, że faszyzm miał pewne cechy totalitarne, jednak nie w pełni zrealizowane. W szczególności w piątym tomie biografii Mussoliniego pt. Lo Stato totalitario podkreślał, że w drugiej połowie lat 30. nastąpiła postępująca totalitaryzacja państwa faszystowskiego przejawiająca się w intensyfikacji faszyzacji społeczeństwa, wychowywaniu nowych pokoleń $\mathrm{w}$ duchu totalitarnym, propagandowej kampanii antyburżuazyjnej oraz wprowadzeniu ustaw rasistowskich. Pozostając jednak wiernym koncepcji Arendt, która zaliczała terror masowy do istotnych wykładników totalitaryzmu, De Felice wykazywał niepełny charakter włoskiej wersji totalitaryzmu ze względu na fakt, że nie posługiwał się on na szeroką skalę środkami terroru i nie stworzył sieci obozów koncentracyjnych ${ }^{23}$.

$\mathrm{Z}$ tą koncepcją nie zgadza się Emilio Gentile, który powołując się na badania hiszpańskiego politologa Juana J. Linza, stwierdza, że terror nie jest elementem wystarczającym do charakterystyki systemu totalitarnego, o czym świadczy fakt, że przed Arendt inni badacze nie zaliczyli go do istotnych elementów totalitary$\mathrm{zmu}^{24}$. Zdaniem cytowanego historyka interpretację autorki Korzeni totalitaryzmu należy uznać za niekonsekwentną i błędną pod względem historycznym. Jak zaznaczył Gentile, u źródeł interpretacji faszyzmu niemieckiej filozof leży niedoskonała znajomość historii i charakteru partii oraz reżimu politycznego włoskiego faszyzmu. W szczególności zwraca uwagę na brak wykorzystania przez Arendt źródeł i danych bibliograficznych odnoszących się do faszyzmu opublikowanych w języku angielskim w latach 30. i 40. (m.in. Alfreda Cobbana, Emila Lederera, Sigmunda Neumanna) oraz studium Luigiego Sturzo L'Italie et le Fascisme, które ukazało się w Paryżu w 1927 r. Jak wykazał, wizja faszyzmu Hannah Arendt opiera się na faszystowskiej publikacji propagandowej wydanej w języku angielskim przez Konfederację przemysłowców faszystowskich zbiorku przemówień Mussoliniego na temat państwa korporacyjnego oraz publikacji Franza Neumanna o narodowym socjalizmie pt. Behemoth ${ }^{25}$.

Gentile krytykuje również tezę Arend, iż włoski faszyzm, w odróżnieniu od narodowego socjalizmu, nie był ruchem totalitarnym i aż do 1938 r. stanowił jedynie dyktaturę nacjonalistyczną jednej partii, podobnie jak Hiszpania Franco,

${ }^{22}$ Zob. R. De Felice, Intervista sul fascismo, red. M.A. Ledeen, Roma-Bari 1975. Koncepcja ta została także przedstawiona w definicji faszyzmu zamieszczonej w Enciclopedia del Novecento w 1977 r., we wstępie do antologii Il fascismo. L'interpretazione dei contemporanei e degli storici oraz w piątym tomie biografii Mussoliniego pt. Lo Stato totalitario w 1981 r. Można ją również odnaleźć w interpretacjach faszyzmu De Felice z lat 80 (zob. R. De Felice, Le Fascisme. Un totalitarisme à l'italienne?, Paris 1988, s. 32).

23 R. De Felice, Il fenomeno fascista, „Storia contemporanea”, październik 1979, s. 627.

24 J.J. Linz, Totalitarian and Authoritarian Regimes, Boulder 2000, s. 74.

25 F. Neumann, Behemoth. Struttura e pratica del nazionalsocialismo, Milano 1977. Cyt. za: E. Gentile, Fascismo. Storia e interpretazioni..., s. 63. 
Portugalia Salazara czy nawet Polska Piłsudskiego. Jak zwrócił uwagę, żaden z cytowanych systemów autorytarnych nie stworzył ruchu masowego zorganizowanego w partię-milicję, która przejęłaby władzę, tworząc reżim jednej partii rządzącej i reprezentujący integralną wizję polityczną zakładającą pełne podporządkowanie jednostki państwu, sakralizację narodu, wysławianie nienawiści i wojny jako cnót obywatelskich oraz wychowanie w duchu wojskowym młodego pokolenia. Autor Il culto del littorio odrzuca też tezę Arendt o relacjach pomiędzy reżimem faszystowskim i Kościołem. Jak pisze, Kościół zgodził się na kompromis z reżimem faszystowskim, podobnie jak postąpił w III Rzeszy, zdając sobie jednak sprawę, że reżim Mussoliniego miał zasadniczo charakter antychrześcijański i totalitarny, dążący do wchłonięcia katolicyzmu przez własną religię polityczną ${ }^{26}$. Oczywiście Mussolini postępował z Kościołem w sposób mniej agresywny, niż czynił to Hitler, lecz należy pamiętać, że katolicy i księża antyfaszystowscy nie uniknęli prześladowań, o czym świadczy m.in. przypadek księdza Luigiego Sturzo, który w 1924 r. został zmuszony do opuszczenia Włoch.

Zdaniem Gentilego faszyzm był raczej „eksperymentem” niż „reżimem” totalitarnym, zważywszy na jego charakter dynamiczny, ciągły proces, który nie dobiegł końca i był dużo bardziej zaakcentowany tuż przed wybuchem II wojny światowej niż pod koniec lat 20 . W koncepcji cytowanego historyka reżim totalitarny jest systemem politycznym opierającym się na pełnej symbiozie państwa, partii i instytucji kierowanych przez nową arystokrację partyjną, wybraną przez przywódcę monopartii, który dzięki swojej charyzmie sprawuje pełnię władzy nad całą strukturą reżimu. Totalitarny system polityczny działa jak laboratorium, w którym prowadzi się eksperymenty nad rewolucją antropologiczną w celu stworzenia nowego typu człowieka. Totalitaryzm charakteryzuje dynamizm, który objawia się w stałej rewolucji, ciągłej ekspansji władzy politycznej i nieustającej intensyfikacji kontroli nad społeczeństwem w celu podporządkowania mas i zintegrowania ich w państwie. W tym sensie totalitaryzm faszystowski był więc „eksperymentem”, który realizował się stopniowo w kulturze politycznej, przejmując stopniowo kontrolę nad instytucjami politycznymi i kontrolując wszystkie aspekty życia reżimu dzięki złożonej relacji pomiędzy ideologią, partią i reżimem. Jak zauważył Gentile, dotyczył on nie tylko polityki wewnętrznej, funkcjonowania instytucji państwa, społeczeństwa, świata kultury, lecz także wpłynął na prowadzenie polityki zagranicznej. W latach 30 . proces totalitaryzacji państwa nabrał we Włoszech rozpędu i postępował w trzech kierunkach: 1) w stronę opracowania definicji ideologicznej państwa totalitarnego; 2) w kierunku systematycznego poszerzania form organizacji i mobilizacji mas, pod kierunkiem PNF i 3) ku pełnej koncentracji władzy i ekspansji PNF w społeczeństwie i państwie.

${ }^{26}$ E. Gentile, La via italiana al totalitarismo..., s. 323. 
Gentile podziela tezę De Felicego, że po zwycięskiej wojnie w Etiopii nastąpiło świadome przyspieszenie procesu totalitaryzacji społeczeństwa i państwa, o czym świadczy zlikwidowanie w 1936 r. Izby Deputowanych i stworzenie Izby Korporacji Faszystowskich, wprowadzenie ustaw rasistowskich w 1938 r., ustanowienie ministerstwa Kultury Ludowej (Minculpop), przeprowadzenie reformy szkolnictwa (Carta della scuola) i przejęcie kontroli nad wychowaniem nowych pokoleń oraz prowadzenie ofensywy przeciwko Kościołowi ${ }^{27}$. Zgadza się także z twierdzeniem, że faszystowski eksperyment totalitarny napotkał przeszkody i opór ze strony tradycyjnych instytucji, na czele z Kościołem i monarchią, które przez długi czas żyły iluzją, iż pozostanie on reżimem autorytarnym, umocnionym ich wsparciem, masowym poparciem społeczeństwa i mitem duce. Jak podkreślił historyk, pod koniec lat 30. zarówno hierarchia kościelna, jak i król Wiktor Emanuel III zdali sobie jednak sprawę z klęski próby powstrzymania procesu totalitaryzacji państwa. Wyraźnie świadczą o tym słowa kardynała Mediolanu Alfredo Schustera wypowiedziane na Konferencji Biskupów Regionu Lombardii w 1939 r., który stwierdził klęskę polityki pojednania reżimu Mussoliniego i Kościoła oraz niebezpieczeństwo związane z rozprzestrzenianiem się we Włoszech nowej religii laickiej, ,religii faszystowskiej”:

wobec szerzenia się systemu filozoficzno-religijnego, który zakłada negację Credo apostolskiego, transcendencji duchowej religii, praw rodziny chrześcijańskiej i jednostki [...], narzucenia credo faszystowskiego i tworzenia państwa totalitarnego, które chce przejąć atrybuty boskie [...], Konkordat wyparowa ${ }^{28}$.

Podobnie diarchia Mussoliniego i króla w rzeczywistości była zupełną fikcją. Jak wykazał Gentile, królowi nie udało się nigdy zapobiec ani ograniczyć procesu systematycznego rozmontowywania porządku konstytucyjnego opierającego się na Statucie Albertyńskim ani przeciwdziałać tendencjom antyliberalnym i antydemokratycznym. Jak wiadomo, Wiktor Emanuel III nie udaremnił wprowadzenia ustaw rasistowskich, a kiedy po zakończeniu wojny miał udokumentować działania monarchii $\mathrm{w}$ celu zablokowania postępującej totalitaryzacji państwa, był w stanie wykazać jedynie opóźnienie o rok wprowadzenia dekretu ograniczającego wolność prasy w 1924 r. ${ }^{29}$ Oczywiście faszyzmowi nie udało się zrealizować wszystkich ambicji totalitarnych. Jak zaznaczył Gentile, było to jednak spowodowane nie tyle oporem tradycyjnych instytucji, ile klęską militarną Włoch w II wojnie światowej. Monarchia wkroczyła do gry dopiero w momencie, gdy Wielka Rada Faszystowska przegłosowała wotum nieufności dla duce, przypieczętowując w ten sposób upadek reżimu.

27 R. De Felice, Mussolini il duce. Lo Stato totalitario 1936-1940..., s. 8 n.

28 Zob. P. Beltrame Quattrocchi, Al di sopra dei gagliardetti, Casale Monferrato 1985, s. 260

262. Cyt. za: E. Gentile, Fascismo. Storia e interpretazione..., s. 69.

29 E. Gentile, Fascismo. Storia e interpretazione..., s. 70. 
Nie można zaprzeczyć, że eksperyment totalitarny włoskiego faszyzmu różnił się od eksperymentów totalitarnych komunizmu i narodowego socjalizmu. Gentile częściowo zgadza się z interpretacją faszyzmu jako "totalitaryzmu niepełnego” „totalitaryzmu niedoskonałego” czy „totalitaryzmu niedokończonego”, aczkolwiek podkreśla, że we wszystkich totalitaryzmach, zarówno w wypadku III Rzeszy, jak i ZSRR, nie brakowało oporu i przeszkód, a reżim dyktatorski nigdy nie sprawował pełnego monopolu władzy — podobnie jak podporządkowanie społeczeństwa nie zostało w pełni zrealizowane, rewolucja antropologiczna nie doprowadziła do stworzenia idealnego modelu człowieka zgodnie ze określoną wizją ideologiczną, a laicka religia polityczna nie przekształciła zbiorowości społeczeństwa we wspólnotę wierzących ${ }^{30}$. Stąd zdaniem Gentilego żaden z eksperymentów totalitarnych w XX w. nie może zostać zdefiniowany jako ,pełny” i „,doskonały”.

\section{Faszyzm jako ,ideologia antyideologiczna”}

Aż do lat 60. we włoskiej historiografii dominowało przekonanie, że faszyzm nie posiadał własnej ideologii lub że znakomita część jego programu została przejęta z doktryny włoskiego nacjonalizmu. Większość badaczy kwalifikowała faszyzm jako reakcję na marksizm i liberalizm ${ }^{31}$. Była więc ideologią „,negatywną”, cechującą się antydemokratyzmem, antyliberalizmem, antyparlamentaryzmem i pozbawioną jakichkolwiek sformułowań pozytywnych ${ }^{32}$. Badania prowadzone przez Emilio Gentilego w latach 70. przyczyniły się zasadniczo do obalenia tej tezy ${ }^{33}$. Zdaniem interesującego nas historyka ideologia stała się integralną częścią działania i postaw faszyzmu, aczkolwiek nie miała charakteru intelektualnej teorii opracowanej przed powstaniem związków kombatanckich. Była zarówno kreacją Mussoliniego, wynikiem ewolucji jego koncepcji politycznych, a mianowicie przejścia od socjalizmu do interwencjonizmu, jak i wyrazem całego systemu wierzeń, idei, mitów oraz symboli ruchu wyrosłego z doświadczeń Wielkiej Wojny i z antysocjalistycznej reakcji klas średnich. Chociaż Gentile zgadza się z twierdzeniem, że źródłem ideologii faszystowskiej była krytyka innych ideologii politycznych wywodzących się z pozytywizmu i historyzmu, które nie sprawdziły się w trudnych latach kryzysu powojennego, i niezaprzeczalnie jej cechą był

30 Ibidem, s. 70-71.

31 Jest znamienne, że we Włoszech nie cieszyły się popularnością studia historyków Ernesta Noltego, Eugena Webera, George'a L. Mossego, Jamesa A. Gregora, którzy chociaż zasadniczo różnili się w swoich interpretacjach, niemniej jednak już w latach 60 . wskazywali na istnienie programu ideologicznego faszyzmu.

32 Zob. N. Bobbio, Il regime fascista, [w:] F. Antonicelli, Trent'anni di storia italiana (19151945), Torino 1961, s. 154; idem, La cultura e il fascismo, [w:] G. Quazza, Fascismo e la società italiana, Torino 1973, s. 211.

${ }^{33}$ E. Gentile, Alcune considerazioni sull 'ideologia fascista, „Storia Contemporanea”, marzec 1974, s. 115-125. 
antymaterializm, antyindywidualizm, antyliberalizm, antydemokratyzm i antymarksizm, to podkreśla, że cechowała się ona także ultranacjonalizmem i populizmem. Niezaprzeczalnie ideologia faszyzmu była wynikiem doświadczeń I wojny światowej, jednak pewne jej elementy można znaleźć we wcześniejszych ideologiach politycznych, zarówno prawicowych, jak i lewicowych. Gentile upatruje jej źródeł w tradycji jakobińskiej, w mitach i liturgii laickich ruchów masowych XIX w., w neoromantyzmie, irracjonalizmie, spirytualizmie i woluntaryzmie, lecz także w aktywizmie, antyparlamentaryzmie radykalnych ruchów antyliberalnych nowej rewolucyjnej prawicy czy nowej rewolucyjnej lewicy okresu poprzedzającego wybuch I wojny światowej ${ }^{34}$.

Ideologia faszystowska opierała się na nowoczesnej idei polityki masowej, w której zasadniczą rolę odgrywały elementy irracjonalne (takie jak mity, emocje, ideały i formy zachowań), nadające działalności politycznej charakter sakralny. Oryginalny charakter faszyzmu polegał właśnie na stworzeniu nowej kultury politycznej, wykorzystującej wspomniane mity, wierzenia i symbole, co Gentile zdefiniował jako „racjonalne użycie irracjonalności”. Wykorzystanie instrumentalne mitu narodu przez ruch faszystowski doprowadziło do stworzenia reżimu, w którym życie indywidualne i interesy jednostki zostały podporządkowane supremacji państwa. Było to możliwe dzięki totalnej organizacji społeczeństwa osiągniętej poprzez użycie najrozmaitszych środków, łącznie z użyciem siły i „faszyzacją kultu ojczyzny” 35 . Pełna identyfikacja narodu i faszyzmu pozwalała na prześladowanie przeciwników politycznych, przedstawianych jako wrogów ojczyzny, którzy nie wyznawali tych samych wartości narodowych. Stąd użycie wobec nich siły i przemocy było w pełni usprawiedliwione dobrem naro$\mathrm{du}$, przybierając formę „krucjaty zdrowych sił narodu przeciwko wrogom wewnętrznym”. W faszyzmie ideologia stała się ,ideą-siłą”, syntezą systemu działań i wierzeń wykorzystanych w praktyce. W koncepcji Emilio Gentilego ideologia faszyzmu była więc „,najpełniejszą realizacją państwa totalitarnego, zbudowanego na prymacie polityki i na rozpłynięciu się tego, co prywatne, w tym, co publiczne" ${ }^{36}$. Na ten charakter ideologii faszystowskiej zwrócił już uwagę Palmiro Togliatti w 1928 r., który stwierdził, że mimo iż ideologia faszystowska nie miała charakteru organicznego i konsekwentnego, była jednak niezwykle skuteczna i zapewniała masowe poparcie dla reżimu. Dla przyszłego lidera Włoskiej Partii Komunistycznej elementami tej ideologii była określona koncepcja państwa oraz poparcie drobnej burżuazji.

Zdaniem Emilio Gentilego negowanie istnienia ideologii pozytywnej faszyzmu prowadzi do nieuzmysłowienia sobie przyczyn sukcesu faszyzmu w innych krajach, jak np. we Francji, gdzie nie istniał on praktycznie jako siła polityczna, lecz cieszył się bardzo dużą popularnością. Wykluczając istnienie „pozytywnej” ideologii

34 E. Gentile, Początki ideologii faszystowskiej (1918-1925)..., s. 25.

35 E. Gentile, Storia del partito fascista 1919-1922. Movimento e milizia..., s. 499-500.

36 Ibidem, s. 14. 
faszystowskiej, nie można zrozumieć fascynacji faszyzmem wielu intelektualistów europejskich, m.in. Drieu La Rochelle'a, Roberta Brasillacha czy Louisa-Ferdinanda Céline'a. Dla wspomnianych pisarzy faszyzm stanowił „rewolucję duchową”, reakcję na zdegenerowany materializm kapitalistyczny, z której miał powstać nowy człowiek, odnowiony pod względem duchowym i cielesnym ${ }^{37}$. Zdaniem Gentilego faszyzm jako ideologia, partia i ustrój był pierwszym przejawem nowego, rewolucyjnego i totalitarnego nacjonalizmu, który stał się inspiracją dla innych ruchów i reżimów powstałych w Europie w okresie międzywojennym. Historyk, rozpatrując faszyzm jako zjawisko uniwersalne, stwierdza, iż należy wziąc pod uwagę zarówno wymiar kulturowy jego ideologii, wspólny system wartości, zasad i celów, jak i charakter instytucyjno-organizacyjny, tzn. zespół struktur i relacji tworzących reżim, lecz także skład społeczny, strukturę, styl i metody walki partii. Próbując zdefiniować fenomen faszyzmu, Gentile wyróżnia 10 cech charakterystycznych: 1) istnienie partii-milicji, będącej ruchem masowym o charakterze ponadklasowym, aczkolwiek z wyraźną przewagą klas średnich w warstwach kierowniczych; 2) istnienie ideologii o charakterze ,antyideologicznym” i pragmatycznym, wyrażanej poprzez nowy styl polityczny oraz mity, rytuały i symbole nowej „laickiej religii”; 3) stworzenie nowej kultury politycznej opartej na aktywizmie, micie młodości oraz militaryzacji polityki; 4) występowanie totalitarnej koncepcji prymatu polityki w życiu narodu; 5) powstanie nowej etyki obywatelskiej opierającej się na całkowitym oddaniu wspólnocie narodowej; 6) istnienie jednej partii pełniącej rolę zbrojnego ramienia reżimu; 7) rozbudowany aparat policyjny niewahający się użyć terroru; 8) ściśle zhierarchizowany system polityczny na czele z charyzmatycznym wodzem (duce); 9) stworzenie korporacyjnej organizacji gospodarki; 10) prowadzenie imperialistycznej polityki zagranicznej służącej budowaniu potęgi, wielkości własnego państwa oraz nowej cywilizacji ${ }^{38}$.

\section{Faszyzm jako cezaryzm totalitarny}

Jak podkreślił Emilio Gentile, faszyzmu nie można ograniczyć jedynie do myśli i systemu rządów Benito Mussoliniego. Tendencja do redukowania faszyzmu do „mussolinizmu”, pomijająca istnienie i działalność masowej partii faszystowskiej, jest kolejnym przejawem banalizacji faszyzmu. Zdaniem historyka istnienie silnej monopartii we Włoszech $\mathrm{w}$ dwudziestoleciu międzywojennym nie pozwoliło na pełną personalizację władzy faszystowskiego przywódcy. Zważywszy jednak na dominującą figurę Mussoliniego-duce w organizacji systemu mitów i państwa faszystowskiego, Gentile zdefiniował włoski faszyzm jako „,eezaryzm typu totalitarnego" (cesarismo totalitario), tzn. dyktaturę cezaryjską

37 E. Gentile, Fascismo. Storia e interpretazioni..., s. 79-80.

38 Ibidem, s. 23. 
zbudowaną w oparciu o mit męża opatrznościowego, zintegrowaną ze strukturą organizacyjną partii stanowiącą punkt odniesienia dla działalności i organizacji państwa oraz całego społeczeństwa ${ }^{39}$. Mit Mussoliniego oraz jego rola jako faszystowskiego wodza i szefa rządu stanowiły niewątpliwie charakterystykę systemu politycznego faszyzmu, jednak — jak słusznie zaznaczył Gentile — jego kult jako charyzmatycznego wodza wykształcił się stopniowo. Dopiero po przekształceniu Fasci di combattimento w partię faszystowską Mussolini umocnił swoją pozycję jako wodza. Nie miało to jednak nic wspólnego z jego szczególną charyzmą, ale z faktem, że poszczególne frakcje faszystowskie uznały go za jedyną osobę zdolną utrzymać jedność w partii. Zdaniem Gentilego to właśnie walki wewnętrzne w PNF w latach 1922-1925 doprowadziły do umocnienia mitu Mussoliniego jako duce. Kult duce zrealizował się dopiero w drugiej połowie lat 20., głównie za sprawą sekretarza PNF Augusto Turatiego, wraz z umacniającą się koncepcją faszyzmu jako religii laickiej. Jak podkreślił historyk, mit wodza wpisywał się w kulturę oraz mentalność faszystowską i znalazł swoją podbudowę w teologii politycznej Giovanniego Gentilego, zgodnie z którą Mussolini stał się personifikacją faszystowskiej idei bohatera oraz uprzywilejowanego ducha opatrznościowego. W konsekwencji w latach 1926-1930 nastąpił proces „deifikacji mitu Mussoliniego”, który był przedstawiany przez propagandę faszystowską jako realizator „rewolucji narodowej”, jedyny twórca i przywódca faszyzmu, interpretator ducha narodu (italianità), nowy Cezar i bohater nowej epoki w historii Włoch. To właśnie poprzez połączenie funkcji przywódcy partii i szefa rządu zrealizowała się pełna integracja państwa i partii, a postępującej koncentracji władzy w rękach Mussoliniego towarzyszyła stopniowa dekompozycja systemu liberalnego i tworzenie struktur państwa totalitarnego.

\section{$* * *$}

Koncepcja faszyzmu Emilio Gentilego zasadniczo różni się od interpretacji faszyzmu powstałych na przełomie lat 50. i 70. XX w., które negowały totalitarny charakter włoskiego faszyzmu oraz podważały istnienie ideologii oraz kultury faszystowskiej i w konsekwencji przyczyniły się do powstania zjawiska „banalizacji włoskiego faszyzmu”. Gentile w swojej analizie reżimu Mussoliniego nawiązuje do pierwszych interpretacji opracowanych przez włoskich antyfaszystów już w dwudziestoleciu międzywojennym. Nie zgadza się z bardzo popularną koncepcją faszyzmu jako dyktatury nacjonalistycznej Hannah Arendt. Nie podziela również interpretacji reżimu Mussoliniego jako totalitaryzmu niepełnego, zaproponowanej przez Renzo De Felicego. Podkreśla istnienie pozytywnej faszystowskiej

39 Ibidem, s. 170. 
ideologii oraz kultury politycznej wykorzystującej w praktyce mity, symbole, rytuały i próbującej stworzyć nową religię laicką.

Włoski historyk wskazuje na postępujący proces totalitaryzacji państwa w drugiej połowie lat 30. i zwracając uwagę na dynamiczny charakter tego procesu, definiuje faszyzm jako „eksperyment totalitarny” oraz „włoską drogę do totalitaryzmu". W koncepcji Gentilego faszyzm był totalitaryzmem modernistycznym, stanowiącym przejaw nowego, rewolucyjnego nacjonalizmu, zorganizowanego w jednej masowej partii, która zdobyła pełnię władzy, likwidując demokrację parlamentarną oraz instytucje liberalne i budując na ich gruzach nowe państwo totalne.

\section{Bibliografia}

Alla ricerca dell'Italia contemporanea. Romeo, De Felice, Spadolini. Atti del convegno di studi svoltosi a Firenze il 21-22 novembre 1997, red. G. Giarizzo, Firenze 2002.

Amendola G., Un anno dopo, ,Il Mondo”, 2 listopada 1923, [w:] idem, In difesa dell 'Italia liberale. Scritti e discorsi politici, 1910-1925, red. A. Carioti, Firenze 2001.

Aquarone A., L'organizzazione dello Stato totalitario, Torino 1965.

Arendt H., Le origini del totalitarismo, Torino 2009.

Baldassini C., L'ombra di Mussolini.L'Italia moderata e la memoria del fascismo (1945-1960), Soveria Mannelli 2008.

Belardelli G., Il fascismo „umano” dei rotocalchi. Tutto baci e lacrime, „Il Corriere della sera”, 7 kwietnia 2008.

Beltrame Quattrocchi P., Al di sopra dei gagliardetti, Casale Monferrato 1985.

Bobbio N., Il regime fascista, [w:] F. Antonicelli, Trent'anni di storia italiana (1915-1945), Torino 1961.

Bobbio N., La cultura e il fascismo, [w:] G. Quazza, Fascismo e la società italiana, Torino 1973.

Bucciarelli M., Democrazia Fascismo Totalitarismo, „La Rivolta Ideale”, styczeń 1951, nr 4.

Canali M., Repressione e consenso nell'esperimento fascista, [w:] Modernità totalitaria. Il fascismo italiano, red. E. Gentile, Roma-Bari 2008.

De Felice R., Il fascismo. L'interpretazione dei contemporanei e degli storici, Bari 1970.

De Felice R., Il fenomeno fascista, „Storia contemporanea”, październik 1979.

De Felice R., Intervista sul fascismo, red. di M.A. Ledeen, Roma-Bari 1975.

De Felice R., Le Fascisme. Un totalitarisme à l'italienne?, Paris 1988,

De Felice R., Mussolini il duce. Gli anni del consenso 1929-1936, Torino 1974.

De Felice R., Mussolini il duce. Lo Stato totalitario, Torino 1981.

De Felice R., Mussolini il fascista. L'organizzazione dello Stato fascista 1925-1929, Torino 1968.

De Felice R., Mussolini il fascista. La conquista del potere 1921-1925, Torino 1966.

De Felice R., Mussolini il rivoluzionario 1883-1920, Torino 1965.

De Felice R., Storia degli ebrei italiani sotto il fascismo, Torino 1961.

Focardi F., Die Unsitte des Vergleichs. Die Rezeption von Faschismus und Nationalsozialismus in Italien und die Schwirigkeiten, sich der eigenen Vergangenheit zu stellen, [w:] Parallele Geschichte? Italien und Deutschland 1945-2000, red. G.E. Rusconi, H.Woller, Berlin 2006.

Gentile E., Alcune considerazioni sull'ideologia fascista, „Storia Contemporanea”, marzec 1974.

Gentile E., E fu subito regime. Il fascismo e la Marcia su Roma, Roma-Bari 2012.

Gentile E., Fascismo di pietra, Roma-Bari 2007. 
Gentile E., Fascismo e antifascismo. I partiti italiani fra le due guerre, Firenze 2000.

Gentile E., Fascismo. Storia e interpretazione, Roma-Bari 2005.

Gentile E., Il culto del littorio. La sacralizzazione della politica nell'Italia fascista, Roma-Bari 2003.

Gentile E., Il fascismo in tre capitoli, Roma-Bari 2009.

Gentile E., Il mito dello Stato nuovo. Dal radicalismo nazionale al fascismo, Roma-Bari 2002.

Gentile E., La Grande Italia. Il mito della nazione nel XX secolo, Roma-Bari 2006.

Gentile E., La via italiana al. totalitarismo. Il partito e Lo Stato nel regime fascista, Roma 2008.

Gentile E., Le origini dell'ideologia fascista 1918-1925, Bari 1975 (w wersji polskiej: idem, Początki ideologii faszystowskiej, Warszawa 2011).

Gentile E., Le origini dell'Italia contemporanea. L'età giolittiana, Bologna 2009.

Gentile E., Le religioni della politica. Fra democrazie e totalitarismi, Roma-Bari 2007.

Gentile E., Renzo De Felice. Lo storico e il personaggio, Roma-Bari 2003.

Gentile E., Storia del partito fascista 1919-1922. Movimento e milizia, Roma-Bari 1989.

Gentile E., The Struggle for Modernity. Nationalism, Futurism and Fascism, Westport 2003.

Ginsborg P., Berlusconi, Ambizioni patrimoniali in una democrazia mediatica, Torino 2003.

Goglia L., Moro R., Renzo De Felice. Studi e testimonianze, Roma 2002.

Ignazi P., Extreme Right Parties in Western Europe, Oxford 2003.

Interpretazioni su Renzo De Felice, red. P. Chessa, F. Villari, Milano 2002.

Linz J.J., Totalitarian and Authoritarian Regimes, Boulder 2000.

Mantelli B., Fascismus, Geschichte Italiens, Selbstverständnis der Republik. Kritische Anmerkungen zür jüngsten Debatte über die Beziehung von Geschichte und Gegenwart, [w:] Faschismus und Faschismen im Vergleich. Wolfgang Schieder zum 60. Geburstag, red. C. Dipper, R. Hudemann, J. Petersen, Köln 1998.

Mattioli A., „Viva Mussolini”. La guerra della memoria nell'Italia di Berlusconi, Bossi, Fini, Milano 2011.

Modernità totalitaria. Il fascismo italiano, red. E. Gentile, Roma-Bari 2008.

Montanelli I., Il buonomo Mussolini, Milano 1947.

Neumann F., Behemoth. Struttura e pratica del nazionalsocialismo, Milano 1977.

Renner J., Der neue Marsch auf Rom. Berlusconi und seine Vorläufer, Zürich 2002.

Santomassimo G., Il ruolo di Renzo De Felice, [w:] Fascismo e antifascismo. Rimozioni, revisioni, negazioni, red. E. Collotti, Roma-Bari 2003.

Simoncelli P., Renzo De Felice e il fantasma di Mussolini, „Passato e presente”, styczeń-kwiecień 1998.

Simoncelli P., Renzo De Felice. La formazione intellettuale, Firenze 2001.

Salvatorelli L., Nazionalfascismo, Torino 1977.

Sturzo L., L'Italie at le Fascisme, Paris 1927.

Tamaro A., Vent'anni di storia 1922-1943, t. 2, Roma 1953.

Tranfaglia G.N., Fascismo e mass media: dall'intervista di De Felice agli sceneggiati televisivi, „Passato e presente” 1983, nr 3.

\section{RETROACTIVE “TRIVIALIZATION OF FASCISM” ACCORDING TO EMILIO GENTILE'S CONCEPT}

\section{Summary}

The text is devoted to the concept of "retroactive trivialization of fascism" developed at the beginning of the 21 st century by an Italian historian - Emilio Gentile. According to Gentile, the phenomenon of "banalization of fascism", inaugurated in the postwar years in neo-fascist memorialism and 
continued by some of the contemporary historians, consists in: 1) negation of totalitarian character of Italian fascism and presenting it as an authoritarian dictatorship of traditionalistic type; 2) challenging the existence of "positive" fascist ideology, and in 3) characterizing Mussolini's regime as a personal "duce" dictatorship created on the basis of traditional elites. In the Gentile's concept, fascism constituted "an Italian road to totalitarianism", was a totalitarian experiment having its own positive ideology and forming a demonstration of new, revolutionary, and totalitarian nationalism.

Keywords: fascism, interpretations, Emilio Gentile.

Joanna Sondel-Cedarmas

joanna.sondel-cedarmas@uj.edu.pl 